\title{
Understanding Proximity Mobile Payments Adoption in South Africa: A Perceived Risk Perspective
}

\author{
Charlene Eksteen \\ Department of Marketing Management, University of Pretoria, \\ Lynnwood Road, Hatfield, Pretoria, South Africa \\ charleneeksteen@icloud.com \\ Michael Humbani \\ Department of Marketing Management, University of Pretoria, \\ Lynnwood Road, Hatfield, Pretoria, South Africa \\ michael.humbani@up.ac.za \\ https://orcid.org/0000-0002-2416-5016
}

Received: 27 July 2021/ Revised: 2 September 2021/ Accepted: 7 September 2021/ Published online: 15 December 2021

\begin{abstract}
Although existing literature claims that consumers are ready for proximity mobile payments, the reality is that adoption is still low in South Africa. Service providers' attempts to translate this potential into profit is hindered by consumers' perception of risks associated with proximity mobile payments. The purpose of this study was to investigate the perceived risk dimensions as possible inhibitors of proximity mobile payment adoption, as well as to investigate the role of gender differences, drawing from the perceived risk and push-pull theories. Using a convenience sample, data was collected from South African smartphone users, from whom 284 valid online surveys were obtained. The standard regression analysis reveals that financial-security and performance risk are predictors of proximity mobile payment adoption, and that product risk is not a significant predictor, at least in the South African context. The findings also reveal that both genders feel more or less the same about the influence of risk factors on the adoption of mobile proximity payments, except for performance risk. The results also show that females are more concerned about the performance of proximity mobile payments than males. The study provides tangible insights that service providers and marketers can use to guide application development and communication with consumers. A contribution is also made to the limited empirical research on the influence of proximity mobile payment risks on adoption during crisis times.
\end{abstract}

JEL classification: M31, L81

Keywords: financial-security risk, performance risk, product risk, proximity mobile payments, adoption intention, perceived risk theory

* Correspondence: Michael Humbani, University of Pretoria, Lynnwood Road, Department of Marketing Management, Hatfield, Pretoria, South Africa. E-mail: michael.humbani@up.ac.za 


\section{INTRODUCTION}

The use of proximity mobile payments continues to grow unabated. While about $72 \%$ of consumers were already accustomed to using proximity mobile payments in 2019 in America, the number rose by $29 \%$ to 92.3 million in 2020, and is now projected to surpass 100 million by 2025 (Kats, 2021). Southern Africa registered over 50 million new mobile payment accounts in 2019 alone (GSMA, 2019). Suffice to say that the COVID-19 pandemic accounts for a significant change in consumer shopping behaviour and in how they pay for goods and services. Despite consumers becoming increasingly more comfortable with these new buying habits, several factors are inhibiting stronger growth and adoption. The ubiquity of mobile phones means that consumers do not need to carry wallets with cash or cards; instead, they can conveniently use their mobile phones to complete purchases (Zhou, 2013). Nevertheless, when compared with cash or cards, consumers view mobile payments as involving greater risk and uncertainty, which can prevent them from adopting them (Zhou, 2013).

There are two types of mobile payments: proximity and remote mobile payments (Dahlberg et al., 2015). Proximity mobile payments involve purchasing goods at the point of sale using a smartphone application (app) (Pidugu, 2016; Qasim \& Abu-Shanab, 2016). Proximity mobile payments use technologies such as radio frequency identification (RFID), quick response (QR) codes, and near field communication (NFC) (Zhou, 2013). On the other hand, for remote mobile payments, consumers use their short message service (SMS) to complete online purchases, internet payment services, and mobile banking (De Kerviler et al., 2016; Zhou, 2013).

Proximity mobile payments are of particular interest in the context of South Africa for several reasons. There is a myriad of mobile payment apps available in the country, the most popular of which is SnapScan. According to Pymnts (2017), a Mastercard survey revealed that 31\% of respondents used mobile payments, and $70 \%$ of them used apps such as SnapScan, Zapper, FlickPay, and Gust Pay. This study focuses on proximity mobile payments that are applicable to the commonly used apps in South Africa because few studies have investigated why the adoption levels have been low.

These reasons for the transition from cash to digital payments could be divided into push and pull factors. Drawing from the push-pull framework (Wu et al., 2017), negative factors can push people away from using a technology while positive factors can pull people to a technology. Thus, the push-pull framework can be used to understand switching behaviour, which - in the context of this study - is switching from using cash to digital payments. There are several factors that could contribute to push factors within the South African context. First, South Africa has the highest number of COVID-19 infections and deaths on the continent (Galal, 2021). As a way of containing the spread of the virus, the South African government imposed a wide range of restrictions. Reports indicated that the need for social distance and the fear of banknotes as possible virus transmitters have accelerated the adoption of digital payments (Toplin, 2021). Second, there has been an unprecedented rise in contact crimes in South Africa in recent years. Cash withdrawal from automated teller machines (ATMs) is increasingly becoming an easy target for criminals in South Africa, in part due to increased usage and accessibility day and night (BusinessTech, 2021). There has also been an increase in cases where people get robbed in broad daylight, and 1.1 million of these types of cases were recorded in 2019/20 alone (Statistics South Africa, 2020). Based on these statistics, it would be logical for one to believe that there has been a faster transition to digital payments, yet the reality is somewhat disappointing, as only about 6.4 million out of a total of 20 million smartphone users are expected to be users of proximity mobile payments by 2023 (O’Dea, 2020).

Several factors could pull people towards mobile payments. Given that the mobile penetration rate exceeds 90\% (Silver \& Johnson, 2018), South Africans have immense potential to become significant users of proximity mobile payments. More importantly, there is a widespread 
availability of $4 \mathrm{G} / 5 \mathrm{G}$ networks and access to free WiFi in hotspots across cities of South Africa, coupled with a stable regulatory framework (Killian \& Kabanda, 2017). As such, one would expect proximity mobile payments to be commonplace, yet the reality on the ground is not commensurate.

Existing literature points to several barriers to the use of mobile payments. Among the top barriers is users' perception of risk, which apparently prevents service providers from translating this potential into profit and consumers from feeling comfortable using their mobile phones to pay for services (eMarketer, 2021; Humbani \& Wiese, 2018). Thus, this study addresses the following research question: To what extent can consumers' perception of risk deter them from adopting and using proximity mobile payments? Answering this question is crucial as service providers will fail to make returns on their investments if consumers do not adopt and continuously use the payment apps (Oliveira et al., 2016).

This study is grounded in the perceived risk theory, which states that the level of risk consumers perceive a purchase to have will influence their actual purchase behaviour (Tian-Que, 2012). The perceived risk theory is appropriate for this study for two reasons. First, given the lack of familiarity with proximity mobile payments and their relative infancy in developing countries such as South Africa, it is likely that consumers will form a negative attitude towards proximity mobile payments, affecting their adoption (De Kerviler et al., 2016; Slade et al., 2015). Second, the adoption of innovative services is influenced more by perceived losses than by perceived gains (Yang et al., 2015). Prior studies indicated that several risks are associated with mobile payments (Ariffin et al., 2018; Yang et al., 2015). This study investigates the impact of perceived financial, security, product, and performance risk factors on the adoption of proximity mobile payments in the context of an emerging market. Further investigation of these factors is warranted as they have been found in previous studies to be significant negative predictors of mobile technology adoption (Ariffin et al., 2018; Kshetri \& Acharya, 2012; Liu et al., 2012; Yang et al., 2015). Since these studies were predominantly conducted in Asia and Europe, there is a knowledge gap as the contexts are politically, technologically and culturally different from that of South Africa, which is characterised by a high crime rate, unstable networks, and regular load shedding (interruption of electricity supply) (eNCA, 2019; Kelly, 2020). To understand the degree to which the perception of risk hinders the adoption of proximity mobile payments, it was important to investigate the phenomenon in modern times in a South African context with a view to recommending ways to increase adoption.

Gender has been a significant variable in the consumption behaviour literature, such that understanding gender differences could be valuable to marketers in developing marketing strategies for each group (Hamza \& Shah, 2014; Zhang et al., 2018). According to Zhang et al. (2018, p. 4), males and females have different perceptions of and behaviour towards mobile technology "due to their different socially constructed cognitive structures to encode and process information". Since gender has been shown to affect consumption behaviour across different contexts, it was prudent to investigate whether gender differences affect perceptions of risk, with a view to further the understanding of proximity mobile payment adoption.

Thus, the primary objective of this study was to determine the influence of risk factors on the adoption of proximity mobile payments and to determine whether gender differences play a role in risk perceptions. More specifically, the study aimed to investigate the relationship between financial, security, product, and performance risks and the intention to adopt proximity mobile payments by targeting consumers aged 18 years and older who own a smartphone. Furthermore, the study aimed to determine if gender differences impact consumers' perception of risk with a view to recommending practical targeting insights for practitioners.

The contributions of this study were examined from both theoretical and practical perspectives. First, the study contributes to previous quantitative research on mobile payment risks by heeding the call of Slade et al. (2015) that scholars should investigate proximity and remote mobile 
payment separately, as the risks affecting the two modes of payments differ significantly. Second, the study drew from both the push-pull theory and the perceived risk theory to add to the body of existing knowledge on the influence of perceived risks on the adoption of proximity mobile payments from an emerging market perspective. Practically, the study provides valuable insights to marketers and service providers on how to circumvent the proximity mobile payment risks that consumers see as a reason to avoid using them so as to devise strategies that increase adoption. More so, the findings may provide invaluable insights to management on how to segment markets according to gender differences.

The remainder of this research paper consists of the following five sections: a literature review; a description of the conceptual model; the research methodology; the interpretation of the results; and insights to management on how to consider the element of risk in developing proximity mobile payment apps that consumers will actually use.

\section{LITERATURE REVIEW}

\subsection{Overview of Mobile Payments in South Africa}

A recent study by Mastercard found that $73 \%$ of banked consumers are ready to pay with their phones and that $44 \%$ of informal merchants are interested in proximity mobile payment apps (Deloitte, 2019). However, only 14\% of point-of-sale terminals support contactless payments in South Africa, and more than $50 \%$ of consumers still use cash to conduct transactions (Pymnts, 2017). Thus, it is important to understand the slow uptake of proximity mobile payments in South Africa in order to inform appropriate marketing strategies that can enhance adoption.

A recent report indicated that of the available proximity mobile payment service providers, the most popular is Masterpass (65\%), followed by SnapScan (19\%) and Zapper (16\%) (Arde, 2019). Through Masterpass, Mastercard organised the market and facilitated the adoption of QR code technology by partnering with major banks and two proximity mobile payment service providers (Zapper and SnapScan) (Deloitte, 2019). As a result, major banks, such as Standard Bank, Absa, Nedbank and Capitec, all provide Masterpass applications that can be used to pay any merchant that displays a Masterpass, Zapper, SnapScan, or Pay@ QR code (Arde, 2019). Many mobile food delivery apps available in South Africa, including Uber Eats, Checkers Sixty60, UCOOK and Woolworths, also use proximity mobile payment technology.

\subsection{Adoption of Mobile Payments}

Islam et al. (2011) defined 'adoption' as a consumer's intention to continue using a product. Straub (2009) described 'adoption' as a consumer's choice whether to accept or reject an innovation. Adoption takes place when mobile payments align with consumers' values and beliefs in addition to meeting their expectations (Humbani \& Wiese, 2019). This study defines 'adoption' as the process consumers go through from initially becoming aware of a mobile payment app to downloading and using the app.

\subsection{Conceptual Framework, Theoretical Background, and Hypotheses}

The perceived risk theory was first introduced to the marketing world by Bauer (1960), and has since been used to study consumer behaviour in various contexts, including internet banking, smart home technology, mobile payments, and online shopping (Ariffin et al., 2018; Hubert et al., 2019; Roy et al., 2017). 
According to Bauer (1960), every decision that consumers make will involve risk as they cannot predict with absolute certainty the consequences of a decision; and in some cases, those consequences may be unpleasant. Accordingly, researchers have identified various types of consequences that form the sub-dimensions of risk. For instance, Ariffin et al. (2018) investigated the adoption of online shopping using six sub-dimensions of perceived risk, namely product, psychological, time, security, financial, and social risks. Similarly, Liu et al. (2013) used psychological and financial risks in addition to privacy risk and performance risk to investigate NFC payment adoption. This illustrates the multi-dimensional nature of the construct 'perceived risk'.

Perceived risk could be high in the context of South Africa, which is characterised by a high crime rate and regular load shedding, as previously alluded to, which potentially increases the security and performance risks that consumers perceive proximity mobile payments to have. This is supported by Kshetri and Acharya (2012), who reported that developing countries are likely to be affected more by security risks than developed countries because of lack of proper cybercrime legal frameworks and enforcement mechanisms. In this regard, financial, security, product, and performance risks were investigated in this study owing to their significant negative influence on consumers' intention to adopt mobile technologies, as depicted in this study's proposed conceptual model in Figure 1.

Figure 1

Proposed conceptual model of the adoption of mobile payments

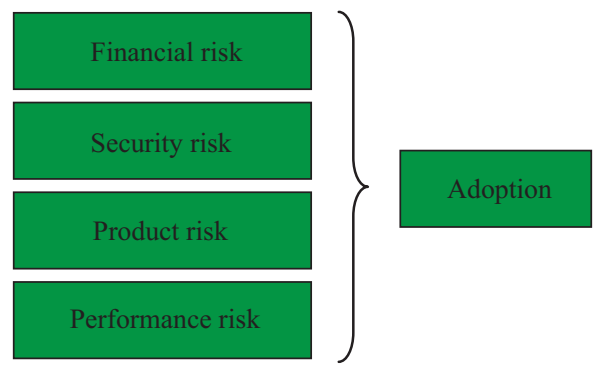

\subsection{Perceived Risk Factors That Influence the Adoption of Proximity Mobile Payments}

\subsubsection{Financial risk}

Yang et al. (2015) defined financial risk as the probability of a mobile app user suffering monetary loss caused by the usage of the mobile payment app. Consumers experience uncertainty because using proximity mobile payments requires them to give out confidential information, such as their bank card details and personal details. This uncertainty is rooted in the potential of a consumer's bank card details being stolen through hacking or malicious software being embedded in the QR codes, resulting in the consumer losing money (Ariffin et al., 2018).

According to Liu et al. (2012), financial risk has become one of the most significant risk dimensions that influences mobile payment adoption. Similarly, Yang et al. (2015) found that of the five dimensions of risk addressed in their study, financial risk had the strongest negative influence on the adoption of mobile payments. However, both Liu et al. (2012) and Yang et al. (2015) conducted their study in the context of China; so further research into financial risk is warranted to establish whether the same is true in the South African context.

There is a general consensus among scholars that females are generally more risk averse than males (Zhang et al., 2018; Yang \& Lee, 2010). Lwoga and Lwoga (2017) reported that Tanzanian females in the agricultural sector are more susceptible to financial risk because of lack of knowledge about mobile payments and because they are considered less innovative compared to males. Based on the above, it is hypothesised that: 
$\mathrm{H}_{1 \mathrm{a}}$ : There is a negative relationship between financial risk and the adoption of proximity mobile payments.

$\mathrm{H}_{1 \mathrm{~b}}$ : Males and females differ with regard to their perceived financial risk of proximity mobile payments.

\subsubsection{Security Risk}

Owing to insufficient standards and regulations, various proximity mobile payment service providers such as Zapper and SnapScan have different levels of security (Pinchot et al., 2016). Thus, consumers are concerned about whether their chosen proximity mobile payments service provider has the appropriate security measures in place to be able to protect their sensitive information.

Ariffin et al. (2018) defined 'security risk' as a loss that occurs when hackers compromise the security of the consumer's online transaction. Consumers will only use the service if they believe their information is safe. As a result, security risk is a direct determinant of mobile payment adoption (Oliveira et al., 2016; Thakur \& Srivastava, 2014).

Developing countries such as South Africa are likely to be affected more by security risks than developed countries because of their underdeveloped cyber-related legal framework and antivirus industry (Kshetri \& Acharya, 2012). Issues of security are a pressing concern in South Africa, which has the third-highest crime rate in the world (World Population Review, 2020). There is a general agreement among scholars that security risk will have a significant negative impact on consumers' willingness to use mobile commerce (Ariffin et al., 2018; Oliveira et al., 2016).

Reports indicated that Tanzanian females in the agricultural sector are more concerned with security risks, primarily due to lack of adequate knowledge about mobile payments and inappropriate security features in the country (Lwoga \& Lwoga, 2017). Many of these females fear the risk of fraud, such as swapping of SIM cards and password leakage, during a transaction. Based on the above, it is hypothesised that:

$\mathrm{H}_{2 \mathrm{a}}$ : There is a negative relationship between security risk and the adoption of proximity mobile payments.

$\mathrm{H}_{2 \mathrm{~b}}$ : Males and females differ with regard to their perceived security risk of proximity mobile payments.

\subsubsection{Product Risk}

According to Marriott and Williams (2018), one of the constraints consumers have to overcome when buying a product using the internet is the technical complexity involved. As the risk associated with buying the product increases, the likelihood of consumers purchasing on the internet decreases (Marriott \& Williams, 2018). In this study, 'product risk' is defined as the potential to experience a loss because consumers are unable to use a product if it does not work as intended or when a lack of information about the product causes uncertainty. Product risk has mainly been studied in the context of online shopping and has been found to negatively impact consumers' intention to purchase online (Ariffin et al., 2018; Bhatti et al., 2018; Han \& Kim, 2017; Pheng et al., 2019).

Thakur and Srivastava (2014) investigated the influence of product risk from the perspectives of security, privacy and monetary risks. As previously alluded, females are more risk averse than males (Zhang et al., 2018), and therefore, this study assumes that they are more likely to be vulnerable than males when it comes to security and monetary risks.

The concern that consumers have is how to return a product and how to get their money back should the product fail to meet their expectations. However, this study assumes that product risk 
will have a minimal impact on consumers' adoption intention given that this study focuses on proximity mobile payments (where you can see what you buy) as opposed to remote payments (which can be done online while away from the store). Based on the above, it is hypothesised that:

$\mathrm{H}_{3 \mathrm{a}}$ : There is a negative relationship between product risk and the adoption of proximity mobile payments.

$\mathrm{H}_{3 \mathrm{~b}}$ : Males and females differ with regard to their perceived product risk of proximity mobile payments.

\subsubsection{Performance risk}

When consumers use a product, they expect it to fulfil the purpose for which they obtained it, and therefore, they have a level of expectation based on how they think the product will perform (Chen et al., 2018). These expectations become the standards against which consumers evaluate a product's performance, and dissatisfaction may result if these standards are not met (Chen et al., 2018).

According to Chen and Tsang (2019), 'performance risk' refers to the proximity mobile payment app or mobile phone not performing as intended during a transaction. This nonperformance occurs owing to factors such as mobile phones having limited processing capability and a small screen size (Yang et al., 2015). The speed and availability of a network connection also influence how proximity mobile payment apps perform (Yang et al., 2015). The concern about network connections is especially relevant in South Africa, owing to the detrimental effect that load shedding has had on mobile phone signals (eNCA, 2019). Thus, consumers are faced with the never-ending battle of trying to find a strong enough connection to enable them to use proximity mobile payment apps, and this has created an environment of persistent uncertainty that is not conducive to proximity mobile payment adoption.

According to Zhang et al. (2018), females have an emotional attachment to mobile services while males are more task oriented. Male consumers find proximity mobile payments to be quite easy to use compared to females (Lwoga \& Lwoga, 2017). This suggests that males are less likely to be hindered by the perception of performance risk than females.

Yang et al. (2015) and Chen and Tsang (2019) found that performance risk negatively influences consumers' willingness to adopt mobile payments. Based on the above, it is hypothesised that:

$\mathrm{H}_{4 \mathrm{a}}$ : There is a negative relationship between performance risk and the adoption of proximity mobile payments.

$\mathrm{H}_{4 \mathrm{~b}}$ : Males and females differ with regard to their perceived performance risk of proximity mobile payments.

\section{METHODOLOGY}

\subsection{Research Design, Sampling, and Population}

The study population consisted of South Africans aged 18 years and older who have mobile phones that support proximity mobile payment apps.

A cross-sectional study aims to determine the prevalence of a phenomenon, which helps obtain the overall picture at one point in time (Kumar, 2019). The combination of a cross-sectional study and a quantitative research design allows a study's findings to be more generalisable to the population (Quinlan et al., 2015). A descriptive research design helps to better describe and validate a specific phenomenon that has been researched before (Omair, 2015). Thus, by using a descriptive research design in this study, previous proximity mobile payment risks could be investigated further, which is especially important in South Africa, where such research is scarce. 
Thus, a cross-sectional study was used in support of a quantitative and descriptive research design to investigate the perception of the risks of proximity mobile payments in the context of South Africa.

This study used a survey method, as surveys can reach a large geographical area to make the findings more generalisable to the population (Siers, 2017). Specifically, this study used an online survey, which offers additional benefits such as quicker collection of responses, saving costs, and simplifying the transfer of data while protecting against data loss (Lefever et al., 2007). This study used a non-probability sampling method based on convenience sampling, owing to it being easy to carry out and saving time and costs. A similar study by Bhatti et al. (2018) that investigated mobile payment risks used convenience sampling, thus making it appropriate to be used in the context of this study.

\subsection{Questionnaire and Data Collection}

A self-administered online questionnaire consisting four sections was developed for this study. The first section was a brief description of the purpose of the study. The second section contained screening questions to ensure the respondents' suitability. The third section measured the consumers' perception of financial, security, product, and performance risk as well as their adoption intention. The fourth section collected demographic information.

In total, 20 scale items were adapted from previous studies of new mobile technologies. More specifically, the eight scale items used to measure financial and performance risk were adapted from the scale items of Featherman and Pavlou (2003); four scale items from Dai (2007) were adapted to measure product risk; four scale items from Liébana-Cabanillas et al. (2015) were used to measure adoption; and lastly, the four scale items used to measure security risk were adapted from Pinchot et al. (2016). In adapting the scale items for this study, the wording of the scale items was slightly changed to suit the context of the study. In the above studies, all the measures exhibited both validity and reliability as Cronbach's alpha values ranged from 0.7 to 0.9. A seven-point Likert response format was used to measure the scale items, where 1 was strongly disagree and 7 was strongly agree.

Before collecting the data, the questionnaire was tested among 20 respondents to ensure instrument validity. Qualtrics, an online survey platform, was used to administer the questionnaire. A hyperlink to the Qualtrics questionnaire was sent via WhatsApp groups and posted to Facebook.

\section{RESULTS}

\subsection{Sample Profile}

The demographic profile of the respondents in terms of gender, age and race is outlined in Table 1. Of the 284 respondents who took part in the research study, females (58.45\%) constituted the majority of the participants. The respondents were aged between 18 and 71, and the largest group was aged $20-29(44.72 \%)$. Of the $73.24 \%$ who preferred to answer the monthly household income question, the majority of the participants earned up to R45 000 per month (46.84\%). In terms of race, education, and province, white $(69.37 \%)$ respondents, those with a university degree $(62.32 \%)$, and respondents living in Gauteng province $(64.44 \%)$ were the largest groups respectively. Lastly, respondents' usage behaviour with proximity mobile payment apps showed that the majority of the respondents had downloaded (63.38\%) and used (66.55\%) proximity mobile payment apps at the time of the survey. 
Table 1

Sample Profile of Respondents

\begin{tabular}{|c|c|c|c|}
\hline Variable & Response categories & $\mathbf{N}$ & Percentage \\
\hline \multirow{3}{*}{ Gender } & Male & 90 & 31.69 \\
\hline & Female & 166 & 58.45 \\
\hline & Other & 28 & 9.86 \\
\hline \multirow{6}{*}{ Age } & $20-29$ & 127 & 44.72 \\
\hline & $30-39$ & 71 & 25 \\
\hline & $40-49$ & 21 & 7.39 \\
\hline & $50-59$ & 19 & 6.69 \\
\hline & $60-69$ & 13 & 4.58 \\
\hline & Other & 33 & 11.62 \\
\hline \multirow{5}{*}{ Race } & African & 38 & 13.38 \\
\hline & Coloured & 5 & 1.76 \\
\hline & Indian & 10 & 3.52 \\
\hline & White & 197 & 69.37 \\
\hline & Other & 34 & 11.97 \\
\hline
\end{tabular}

\subsection{Exploratory Factor Analysis}

To assess the convergent and discriminant validity of this study's data and to investigate its underlying dimensions, an exploratory factor analysis (EFA), applying principle axis factoring with varimax rotation, was conducted (Hair et al., 2019). To determine whether the data is appropriate for an EFA, Bartlett's test of sphericity should be significant $(p<0.05)$ and the Kaiser-MeyerOlkin (KMO) measure of sampling adequacy value must be equal to or greater than 0.6 (Pallant, 2016). The data was suitable for factor analysis as the KMO was above 0.6 (MSA $=0.957)$ and Bartlett's test of sphericity was significant $(\mathrm{p}<0.05)$ (Pallant, 2016; Tabachnick \& Fiddell, 2013).

The EFA resulted in the extraction of four factors with eigenvalues greater than 1, explaining $61.31 \%$ of the variance. Factor 1 consisted of six items that were aimed at measuring financial risk and security risk, respectively, but instead loaded on to one factor. This factor was then labelled 'financial-security risk'. The resultant new financial-security risk factor involved adjusting $\mathrm{H}_{1}$ and $\mathrm{H}_{2}$.

The remaining three factors, product risk (four items), performance risk (four items) and adoption (four items), were labelled accordingly and are presented in Table 2 along with the number of items that loaded for each factor and the mean score and standard deviation for each item. 
Table 2

Validity and reliability

\begin{tabular}{|c|c|c|c|c|c|c|}
\hline Construct & Mean & $\begin{array}{l}\text { Std. } \\
\text { dev. }\end{array}$ & $\begin{array}{l}\text { Factor } \\
\text { loadings }\end{array}$ & CR & AVE & $\alpha$ \\
\hline Financial-security risk & 3.60 & 1.374 & & 0.9 & 0.5 & 0.900 \\
\hline $\begin{array}{l}\text { Using a mobile payment app would lead to the potential } \\
\text { fraud of my bank account. }\end{array}$ & 3.92 & 1.644 & 0.822 & & & \\
\hline $\begin{array}{l}\text { Using a mobile payment app subjects my bank account } \\
\text { to financial risk. }\end{array}$ & 3.83 & 1.642 & 0.809 & & & \\
\hline $\begin{array}{l}\text { My signing up for and using mobile payment apps would } \\
\text { lead to a financial loss for me. }\end{array}$ & 3.08 & 1.525 & 0.622 & & & \\
\hline $\begin{array}{l}\text { I don't feel secure about my transactions performed using } \\
\text { a mobile payment app. }\end{array}$ & 3.40 & 1.887 & 0.664 & & & \\
\hline $\begin{array}{l}\text { I do not think that my personal payment information is } \\
\text { kept safe when I use a mobile payment app to pay for } \\
\text { a purchase. }\end{array}$ & 3.55 & 1.697 & 0.661 & & & \\
\hline $\begin{array}{l}\text { I am concerned about someone intercepting my payment } \\
\text { information or other data if I use my mobile payment app. }\end{array}$ & 4.07 & 1.817 & 0.615 & & & \\
\hline Product risk & 4.66 & 1.383 & & 0.8 & 0.6 & 0.868 \\
\hline $\begin{array}{l}\text { It is difficult for me to judge a product's quality } \\
\text { adequately before buying it. }\end{array}$ & 4.46 & 1.826 & 0.776 & & & \\
\hline $\begin{array}{l}\text { It is not easy for me to compare the quality of similar } \\
\text { products. }\end{array}$ & 4.24 & 1.825 & 0.820 & & & \\
\hline The product purchased may not work as expected. & 5 & 1.390 & 0.724 & & & \\
\hline $\begin{array}{l}\text { I fear that I might not receive the equivalent quality } \\
\text { of a product or service that I purchased. }\end{array}$ & 4.93 & 1.457 & 0.721 & & & \\
\hline Performance risk & 4.17 & 1.390 & & 0.8 & 0.5 & 0.889 \\
\hline $\begin{array}{l}\text { The mobile payment app's performance may not match } \\
\text { its advertised level. }\end{array}$ & 4.30 & 1.581 & 0.643 & & & \\
\hline $\begin{array}{l}\text { The mobile payment app's servers may not perform well } \\
\text { and process payments incorrectly. }\end{array}$ & 3.86 & 1.647 & 0.666 & & & \\
\hline $\begin{array}{l}\text { The mobile payment app might not perform well and } \\
\text { create problems when I try to pay. }\end{array}$ & 4.39 & 1.631 & 0.809 & & & \\
\hline The mobile payment app may be unstable or blocked. & 4.11 & 1.568 & 0.750 & & & \\
\hline Adoption & 4.68 & 1.528 & & 0.8 & 0.6 & 0.878 \\
\hline I intend to use a mobile payment app to make a purchase. & 4.91 & 1.800 & 0.824 & & & \\
\hline $\begin{array}{l}\text { I will use a mobile payment app instead of other } \\
\text { alternatives such as cash or card. }\end{array}$ & 4.28 & 1.966 & 0.806 & & & \\
\hline $\begin{array}{l}\text { I intend to download a mobile payment app in the next } \\
\text { few months. }\end{array}$ & 4.08 & 1.831 & 0.687 & & & \\
\hline I am willing to use mobile payment apps in the future. & 5.44 & 1.510 & 0.732 & & & \\
\hline
\end{tabular}

\subsection{Validity and Reliability}

The results of the EFA proved support for both convergent and discriminant validity, as the factor loadings surpassed 0.5 (Field, 2013; Hair et al., 2019). The convergent validity was further 
evaluated by analysing the composite reliability (CR) and the average variance extracted (AVE). The findings in Table 2 met the criteria for internal consistency reliability of 0.7 and above for both composite reliability and Cronbach's alpha values for each construct as suggested by Pallant (2016). The scale items were representative of each construct as the AVE exceeded the cut-off point of 0.5 , thus supporting convergent validity (Fornell \& Larcker, 1981).

\subsection{Regression Analyses}

A standard multiple regression analysis was performed to test whether the independent variables of financial-security, product, and performance risks negatively predicted proximity mobile payment adoption. The assumptions of multiple regression were investigated prior to performing the analysis, and the findings showed that there were no violations of the assumptions (Pallant, 2016), as indicated below:

- $\quad$ Based on the equation of Tabachnick and Fiddell (2013), $\mathrm{N}>50+8 \mathrm{~m}(\mathrm{~m}=$ number of independent variables), the final realised sample size of 284 was appropriate as it was above the minimum sample size of 74 respondents.

- The correlations between the independent variables did not exceed 0.9 , and the collinearity diagnostics findings indicated that the tolerance values were less than 0.10 , while the variance inflation factors were below 10 (Pallant, 2016). Thus, multicollinearity and singularity were not present in this study.

- The assumption of normality, linearity, and homoscedasticity was confirmed in this study as the normal probability plot's data points formed a relatively straight diagonal line and the scatterplot showed an approximately rectangular distribution (Pallant, 2016).

- The Mahalanobis distance was inspected to determine the existence of possible outliers, which for this study should not exceed 16.27 as this study used three independent variables (Pallant, 2016). According to Pallant (2016), Cook's distance should not exceed 1, which was the case in this study.

Based on all of the above, a standard multiple regression analysis was performed to conclude the significance of the factors as predictors of proximity mobile payment adoption. The adjusted $\mathrm{R}$-square values for the model are shown in Table 3.

Table 3

Model summaryb

\begin{tabular}{|c|c|c|c|c|}
\hline Model & $\mathbf{R}$ & $\mathbf{R}^{2}$ & Adjusted $\mathbf{R}^{2}$ & Standard error of the estimate \\
\hline 1 & $0.484^{\mathrm{a}}$ & 0.235 & 0.226 & 1.285 \\
\hline
\end{tabular}

a. Predictors: (Constant), Total financial insecurity, Total product risk, Total performance risk.

b. Dependable variable: Total adoption

As shown in Table 3, model 1 had an adjusted R-square of 0.226, which meant that the three factors explained $22.6 \%$ of the variance in the adoption of proximity mobile payments. This low percentage may indicate that there are other risk factors not investigated in this study that potentially predict the adoption of proximity mobile payments.

The findings in Table 4 indicate that the model predicted the adoption of proximity mobile payments, and the findings of the analysis of variance (ANOVA) test conducted in this study indicate that the regression model was significant $(\mathrm{p}<0.00)$ (Pallant, 2016). 
Table 4

ANOVA $^{\mathrm{a}}$

\begin{tabular}{|l|c|c|c|c|c|}
\hline \multicolumn{1}{r}{ Model } & Sum of squares & df & Mean square & F & Sig. \\
\hline Regression & 139.158 & 3 & 46.386 & 28.089 & $0.000^{\mathrm{b}}$ \\
\hline Residual & 454.125 & 275 & 1.651 & & \\
Total & $\mathbf{5 9 3 . 2 8 3}$ & $\mathbf{2 7 8}$ & & & \\
\hline
\end{tabular}

Table 5 contains the $\mathrm{p}$-value, $\mathrm{t}$-value, and coefficients ( $\beta$-value) that determine the significance of the independent variables as predictors of proximity mobile payment adoption.

Table 5

Coefficientsa

\begin{tabular}{|c|c|c|c|}
\hline Model & $\begin{array}{c}\text { Standardised } \\
\text { coefficients beta-value }\end{array}$ & t-value & p-value \\
\hline Constant & & 21.763 & 0.000 \\
\hline Financial-security risk & -0.338 & -5.345 & 0.000 \\
\hline Product risk & 0.051 & 0.858 & 0.392 \\
\hline Performance risk & -0.233 & -3.508 & 0.001 \\
\hline
\end{tabular}

It is evident from Table 5 that financial-security risk $(\beta=-0.338, p<0.05)$ and performance risk $(\beta=-0.233, p<0.05)$ were both significant predictors of proximity mobile payment adoption. Conversely, product risk $(\beta=0.051, p>0.05)$ was found to be an insignificant predictor. The findings show that financial-security risk was the strongest contributor to adoption, followed by performance risk.

\subsection{Hypotheses Testing}

The study first tested four hypotheses on the relationship between the predictors and the adoption of proximity mobile payments. The results of the factor analysis identified three predictors thereof. The resultant three hypotheses are shown in Table 6.

Table 6

Findings of the hypotheses testing

Alternative hypotheses

Result

$\mathrm{H}_{1}$ : There is a negative relationship between financial-security risk and the adoption

of proximity mobile payments

Supported

$\mathrm{H}_{2}$ : There is a negative relationship between product risk and the adoption of proximity mobile payments

Not supported

$\mathrm{H}_{3}$ : There is a negative relationship between performance risk and the adoption of proximity mobile payments

Supported

Figure 2 is a visual representation of the findings that resulted from performing a standard multiple regression analysis to test the hypotheses. 
Figure 2

The extent to which risk dimensions predict proximity mobile payment adoption

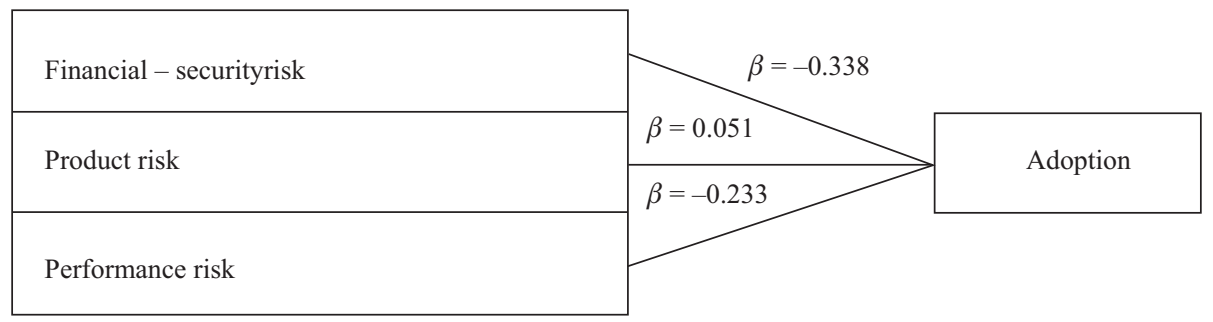

\subsection{Results of Gender Differences}

The study also tested if statistical differences emerged between males and females as regards the relationship between perceived risk factors and adoption of proximity mobile payments. The independent samples T-test was performed and the results in Table 7 indicate only one significant difference between the scores of males $(\mathrm{M}=3.843$; $\mathrm{SD}=1.309)$ and females $(\mathrm{M}=4.266$; $\mathrm{SD}=1.421)$ with regard to the performance risk factor: $(\mathrm{t}(250)=-2.33 ; \mathrm{p}=0.021$, two tailed). The magnitude of the difference in the means (mean difference $=-0.41,95 \%$ ) was very small (eta squared $=0.02$ ). Thus, there was support for $\mathrm{H}_{4 \mathrm{~b}}$ only.

Table 7

Independent samples T-test results with respect to gender differences

\begin{tabular}{|c|c|c|c|c|c|c|}
\hline Variable & Gender & Mean & Std. dev. & DF & $\mathrm{t}$ & p-value \\
\hline Financial-security risk & $\begin{array}{l}\text { Male } \\
\text { Female }\end{array}$ & $\begin{array}{l}3.382 \\
3.707\end{array}$ & $\begin{array}{l}1.389 \\
1.378\end{array}$ & 251 & -1.79 & 0.075 \\
\hline Product risk & $\begin{array}{l}\text { Male } \\
\text { Female }\end{array}$ & $\begin{array}{l}4.466 \\
4.724\end{array}$ & $\begin{array}{l}1.386 \\
1.368\end{array}$ & 251 & -1.42 & 0.156 \\
\hline Performance risk & $\begin{array}{l}\text { Male } \\
\text { Female }\end{array}$ & $\begin{array}{l}3.843 \\
4.266\end{array}$ & $\begin{array}{l}1.309 \\
1.421\end{array}$ & 250 & -2.33 & 0.021 \\
\hline
\end{tabular}

\section{DISCUSSION AND IMPLICATIONS}

The paper presents modest contributions to the ongoing debate on the risk factors that predict the adoption of proximity mobile payments as well as the role that gender plays in the process. Proximity mobile payments are still a relatively new phenomenon in developing countries and still in the infant stages of their development (De Kerviler et al., 2016).

The first objective of the study was to determine the influence of risk factors on the adoption of proximity mobile payments. The findings indicate that financial-security and performance risks are significant predictors of the adoption of proximity mobile payments, while product risk emerged as an insignificant factor. Although most studies address financial risk and security risk separately, in this study the two factors loaded together to make one factor as both factors speak to losses of either information or money that consumers may suffer in completing transactions. The findings of this study are in line with previous research in which performance, financial and security risks were found to have a significant negative influence on the adoption of proximity mobile payments (Chen \& Tsang, 2019; Yang et al., 2015). Similarly, Liu et al. (2012) and Ariffin et al. (2018) also found financial risk and security risk to be the most significant predictors of online purchase intention. 
Contrary to prior findings by Han and Kim (2017) and Pheng et al. (2019), product risk was found to be an insignificant predictor of proximity mobile payment adoption. A plausible explanation might rest with the nature of proximity mobile payments in which consumers are able to touch and see the product before purchase, thus eliminating what is commonly experienced when shopping online (Pheng et al., 2019).

The findings make both academic and practical contributions. Firstly, from a theoretical standpoint, the study drew from two theoretical perspectives (push-pull and risk theories). According to the best knowledge of the authors, no other study has based their research on the two theories to understand the adoption of mobile payments in an African perspective. Secondly, the study adds to the existing body of academic knowledge on the adoption of proximity mobile payments from an emerging market perspective by incorporating factors that have been used less often in a developing country. More so, there seems to be not much of a difference between males and females in the South African context when it comes to their overall perception of risks in general.

From a practical perspective, the results raise noteworthy managerial implications. As expected, South Africa's overall environment of uncertainty, caused by persistent crime (World Population Review, 2020), has resulted in financial-security being a major concern for consumers. To overcome barriers to adoption, service providers can educate consumers on the safety features of proximity mobile payments so as to gain consumer confidence. For example, service providers can use their business websites to disseminate pertinent information by creating a frequently asked questions and answers page or via a 'welcome' email sent out when new consumers sign up. Welcome emails have an $86 \%$ higher open rate than other marketing emails and give service providers the chance to set consumers' expectations (Klongerbo, 2018). So, consumers' expectations about safety can be set from the start, positioning the service provider as a brand that consumers can trust with their financial and private information (Cohen, 2018).

Furthermore, consumers' financial loss concerns arising from potential hacking or fraud through the proximity mobile payment apps can be overcome with a guarantee that the service provider can offer refunds that are equivalent to the loss. Offering a guarantee boosts consumer confidence to trust the level of protection provided in proximity mobile payments (Alton, 2017). South Africa's high crime rate and underdeveloped cyber-related legal framework require service providers to respond quickly to consumer queries (World Population Review, 2020). In the event of the theft of the consumer's mobile phone, service providers can quickly provide a remote deactivation of the account to prevent anyone from using it. Furthermore, working with the government to legislate cybercrime would ease consumers' security concerns. More importantly, proximity mobile payments can also be offered as the solution to fears over contact with contaminated surfaces during the COVID-19 pandemic in service providers' promotional materials.

The findings on performance risk should also be considered to enhance managerial decision-making. Performance concerns can arise from the possibility of the app malfunctioning or not working as intended (Yang et al., 2015). This is particularly true for South Africans who experience regular load shedding (irregular supply of electricity) and social unrest. Consumers fear that if a transaction is incomplete for any reason, they may lose their money in the process. Since the advent of mobile payments in South Africa, it is not clear if consumers can recover their losses after an incomplete transaction. It may be prudent for service providers to work closely with stakeholders in the ecosystem, such as app developers, banks and mobile network operators, to resolve these issues and create an environment that is conducive to mobile payments. For example, banks are more trusted than any other service provider in the ecosystem with respect to security, which also makes them an ideal partner with which to collaborate in integrating the proximity mobile payment apps into mobile banking apps, thus reducing consumers' financial-security concerns (Haripersad \& Sookdeo, 2018). 
As expected, it is not surprising to note that product risk does not deter consumers from engaging in proximity mobile payments. Product risk occurs when a purchased product does not perform to customer expectations (Ariffin et al., 2018). As reported by Marriott and Williams (2018), product risks are considered much higher in online environments as consumers are not physically present in store to make a full judgement regarding the quality of the product. In the case of proximity mobile payments, consumers can check the product physically in store, ask questions from the sales people, and even request a product demonstration if applicable to inform their purchase. Hence, the ability to evaluate a product before purchase makes product risk an insignificant factor in the adoption of proximity mobile payments.

The study also investigated the impact of gender differences on the risk factors and adoption of proximity mobile payments. As indicated, the findings reveal that both genders felt more or less the same about the risk factors and their influence on the adoption of mobile payments, except for performance risk. The results show that females are more concerned about the performance of mobile payments than their male counterparts. The results tally with findings of Marriott and Williams (2018), who reported that females are more strongly influenced by overall performance risks than males. It seems that females in South Africa fear losing their hard-earned money because of unforeseen circumstances such as internet breakdowns caused by consistent load shedding or depletion of data bundles that can result in the unsuccessful processing of transactions. Since proximity mobile payments require the physical presence of the consumers, merchants could provide WiFi hotspots that are not influenced by load shedding to ensure successful completion of transactions.

\section{LIMITATIONS AND RECOMMENDATIONS FOR FUTURE RESEARCH}

This study has limitations that are worth noting, such as its single-country context. Similar studies could be extended to other emerging economies to develop comparisons that reveal if South African consumers are unique or are similar to consumers in different emerging economies (Humbani \& Wiese, 2018). As this study was cross-sectional, a longitudinal study could provide a more complete understanding of the interrelationships among the constructs (Solem, 2015). More so, the use of convenience sampling limits the generalisability of the findings to a wider population.

Further limitations of this study include the focus on three main constructs to identify the adoption intention of respondents. Future studies can investigate a more comprehensive list of risk factors, such as time risk, psychological risk, social risk, that potentially hinder the adoption of proximity mobile payments for a more complete analysis.

\section{References}

Alton, L. (2017, April 26). A look at the benefits of money-back guarantees in modern marketing. Entrepreneur. Retrieved from https://www.entrepreneur.com/article/293330

Arde, A. (2019, April 28). Payments without cash or card a growing trend. TimesLive. Retrieved from https://www. timeslive.co.za/sunday-times/business/2019-04-28-payments-without-cash-or-card-a--growing-trend/

Ariffin, S.K., Mohan, T., \& Goh, Y. (2018). Influence of consumers' perceived risk on consumers' online purchase intention. Journal of Research in Interactive Marketing, 12(3), 309-327. https://doi.org/10.1108/jrim-11-2017-0100

Bauer, R.A. (1960). Consumer behavior as risk taking. In M.J. Baker (Ed.), Marketing: Critical perspectives on business and management. Taylor \& Francis.

Bhatti, A., Saad, S., \& Gbadebo, S.M. (2018). Convenience risk, product risk, and perceived risk influence on online shopping: Moderating effect of attitude. International Journal of Business Management, 3(2), 1-11. 
BusinessTech. (2021, April 3). Beware these 3 banking scams in South Africa. BusinessTech. Retrieved from https:// businesstech.co.za/news/trending/479889/beware-these-3-banking-scams-in-south-africa/

Chen, C., \& Tsang, S. (2019). Predicting adoption of mobile payments from the perspective of taxi drivers. IET Intelligent Transport Systems, 13(7), 1116-1124. https://doi.org/10.1049/iet-its.2018.5437

Chen, X., Carpenter, D., Li, X., Chen, C., \& Hung, S. (2018). Why do individuals continue using mobile payments-A qualitative study in China. In Proceedings of the 51st Hawaii International Conference on System Sciences (pp. 1452-1461). Retrieved from http://hdl.handle.net/10125/50067

Cohen, S. (2018, March 16). How to craft the best welcome email to build trust with new subscribers [blog post]. CoSchedule. Retrieved from https://coschedule.com/blog/welcome-email/

Dahlberg, T., Guo, J., \& Ondrus, J. (2015). A critical review of mobile payment research. Electronic Commerce Research and Applications, 14(5), 265-284. https://doi.org/10.1016/j.elerap.2015.07.006

Dai, B. (2007). The impact of online shopping experience on risk perceptions and online purchase intentions: The moderating role of product category and gender [Doctoral dissertation]. Auburn University.

De Kerviler, G., Demoulin, N.T., \& Zidda, P. (2016). Adoption of in-store mobile payment: Are perceived risk and convenience the only drivers?. Journal of Retailing and Consumer Services, 31, 334-344. https://doi.org/10.1016/j.jretconser.2016.04.011

Deloitte. (2019). The future of payments in South Africa. Retrieved from https://www2.deloitte.com/content/dam/ Deloitte/za/Documents/risk/za-The-future-of-payments-in-South-Africa\%20.pdf

eMarketer. (2021, June 22). Privacy and security are top concerns for digital banking consumers. eMarketer. Retrieved from https://www.emarketer.com/content/top-concerns-digital-banking-consumers?ecid=NL1001

eNCA. (2019, December 12). Costly impact of load-shedding on mobile networks. Retrieved from https://www.enca. com/news/impact-load-shedding-mobile-networks

Featherman, M.S., \& Pavlou, P.A. (2003). Predicting e-services adoption: A perceived risk facets perspective. International Journal of Human-Computer Studies, 59(4), 451-474. https://doi.org/10.1016/s1071-5819(03)00111-3

Field, A. (2013). Discovering statistics using IBM SPSS Statistics (4th ed.). Sage Publications.

Fornell, C., \& Larcker, D.F. (1981). Evaluating structural equation models with unobservable variables and measurement error. Journal of Marketing Research, 18(1), 39-50. https://doi.org/10.2307/3151312

Galal, S. (2021, June 25). Number of coronavirus (COVID-19) deaths in the African continent as of June 24, 2021, by country. Statista. Retrieved from https://www.statista.com/statistics/1170463/coronavirus-cases-in-africa/

GSMA. (2020). State of the industry report on mobile money-2019. Retrieved from https://www.gsma.com/sotir/ wp-content/uploads/2020/03/GSMA-State-of-the-Industry-Report-on-Mobile-Money-2019-Full-Report.pdf

Hair, J.F., Black, W.C., Babin, B.J., \& Anderson, R.E. (2019). Multivariate data analysis (8th ed.). Cengage.

Hamza, A., \& Shah, A. (2014). Gender and mobile payment system adoption among students of tertiary institutions in Nigeria. International Journal of Computer and Information Technology, 3(1), 13-20.

Han, M.C., \& Kim, Y. (2017). Why consumers hesitate to shop online: Perceived risk and product involvement on Taobao.com. Journal of Promotion Management, 23(1), 24-44. https://doi.org/10.1080/10496491.2016.1251530

Haripersad, R., \& Sookdeo, B. (2018). Customer retention: Key towards sustaining competitiveness in commercial banking in South Africa. Journal of Business and Economic Policy, 5(3), 81-90. https://doi.org/10.30845/jbep.v5n3p10

Hubert, M., Blut, M., Brock, C., Zhang, R.W., Koch, V., \& Riedl, R. (2019). The influence of acceptance and adoption drivers on smart home usage. European Journal of Marketing, 53(6), 1073-1098. https://doi.org/10.1108/ejm-12-2016-0794

Humbani, M., \& Wiese, M. (2018). A cashless society for all: Determining consumers' readiness to adopt mobile payment services. Journal of African Business, 19(3), 409-429. https://doi.org/10.1080/15228916.2017.1396792

Humbani, M., \& Wiese, M. (2019). An integrated framework for the adoption and continuance intention to use mobile payment apps. International Journal of Bank Marketing, 37(2), 646-664. https://doi.org/10.1108/ijbm-03-2018-0072

Islam, M.A., Khan, M.A., Ramayah, T., \& Hossain, M.M. (2011). The adoption of mobile commerce service among employed mobile phone users in Bangladesh: Self-efficacy as a moderator. International Business Research, 4(2), 80-89.

https://doi.org/10.5539/ibr.v4n2p80

Kats, R. (2021, May 5). More than 100 million Americans will use proximity mobile payments in 2021. eMarketer. Retrieved from https://www.emarketer.com/content/more-than-100-million-americans-will-use-proximitymobile-payments-2021 
Kelly, S.M. (2020, March 7). Dirty money: The case against using cash during the coronavirus outbreak. CNN Business. Retrieved from https:/edition.cnn.com/2020/03/07/tech/mobile-payments-coronavirus/index.html

Killian, D., \& Kabanda, S. (2017). Mobile payments in South Africa: Middle income earners' perspective. In The Pacific Asia Conference on Information Systems (PACIS) 2017 Proceedings, 53. Retrieved from http://aisel. aisnet.org/pacis2017/53

Klongerbo, S. (2018, June 22). Why you absolutely must send welcome emails to new leads. Retrieved on October 1, 2020 from https:/9clouds.com/blog/why-you-absolutely-must-send-welcome-emails-to-new-leads/

Kshetri, N., \& Acharya, S. (2012). Mobile payments in emerging markets. IT Professional, 14(4), 9-13. https://doi.org/10.1109/mitp.2012.82

Kumar, R. (2019). Research methodology: A step-by-step guide for beginners. Sage Publications.

Liébana-Cabanillas, F., Muñoz-Leiva, F., \& Sánchez-Fernández, J. (2015). Influence of age in the adoption of new mobile payment systems. Revista Brasileira de Gestão de Negócios, 17(58), 1390-1407. https://doi.org/10.7819/rbgn.v17i58.1989

Lefever, S., Dal, M., \& Matthiasdottir, A. (2007). Online data collection in academic research: Advantages and limitations. British Journal of Educational Technology, 38(4), 574-582. https://doi.org/10.1111/j.1467-8535.2006.00638.x

Liu, Y., Kostakos, V., \& Deng, S. (2013). Risks of using NFC mobile payment: investigating the moderating effect of demographic attributes. In Proceedings of the 15th International Conference on Electronic Commerce (pp. 125-134). 15th International Conference on Electronic Commerce, Turku, Finland, 13-15 August.

Liu, Y., Yang, Y., \& Li, H. (2012). A unified risk-benefit analysis framework for investigating mobile payment adoption. Paper presented at the 2012 International Conference on Mobile Business, Delft, Netherlands, 21-22 June. Retrieved from http://aisel.aisnet.org/icmb2012/20

Lwoga, E.T., \& Lwoga, N.B. (2017). User acceptance of mobile payment: The effects of user-centric security, system characteristics and gender. The Electronic Journal of Information Systems in Developing Countries, 81(1), $1-24$. https://doi.org/10.1002/j.1681-4835.2017.tb00595.x

Marriott, H.R \& Williams, M.D. (2018). Exploring consumers perceived risk and trust for mobile shopping: A theoretical framework and empirical study. Journal of Retailing and Consumer Services, 42, 133-146.

O'Dea, S. (2020, December 7). Number of smartphone users in South Africa from 2014 to 2023. Statista. Retreived on March 17, 2020 from https://www.statista.com/statistics/488376/forecast-of-smartphone-users-in-south-africa/

Oliveira, T., Thomas, M., Baptista, G., \& Campos, F. (2016). Mobile payment: understanding the determinants of customer adoption and intention to recommend the technology. Computers in Human Behavior, 61, 404-414. https://doi.org/10.1016/j.chb.2016.03.030

Omair, A. (2015). Selecting the appropriate study design for your research: descriptive study designs. Journal of Health Specialties, 3(3), 153-156.

https://doi.org/10.4103/1658-600x.159892

Pallant, J. (2016). SPSS survival manual: A step by step guide to data analysis using SPSS (6th ed.). McGraw-Hill.

Pheng, L.S., Zainudin, M.Q.H.B., Bajir, A.B., \& Awang, S.N.A.B. (2019). The influence of perceived risks on intention to purchase clothing online. Selangor Business Review, 4(2), 1-7.

Pidugu, K. (2016). Mobile payment adoption in South Africa: A merchant's perspective (Master's dissertation). University of Pretoria. Retrieved from http://hdl.handle.net/2263/52295

Pinchot, J.L., Mishra, S., Paullet, K.L., \& Kohun, F.G. (2016). Exploring barriers to adoption of mobile payments for university students: Lack of awareness, lack of availability, and perceived security risks. Issues in Information Systems, 17(3), 20-30. https://doi.org/10.48009/3 iis_2016_20-30

Pymnts. (2017, June 30). In South Africa, cash is consumers' hands-down choice. Retrieved on November 2, 2020 from https://www.pymnts.com/cash/2017/south-african-consumers-pick-cash/

Qasim, H., \& Abu-Shanab, E. (2016). Drivers of mobile payment acceptance: The impact of network externalities. Information Systems Frontiers, 18(5), 1021-1034. https://doi.org/10.1007/s10796-015-9598-6

Quinlan, C., Babin, B., Carr, J., Griffin, M., \& Zikmund, W.G. (2015). Business research methods. Cengage Learning.

Roy, S.K., Balaji, M., Kesharwani, A., \& Sekhon, H. (2017). Predicting internet banking adoption in India: A perceived risk perspective. Journal of Strategic Marketing, 25(5-6), 418-438. https://doi.org/10.1080/0965254x.2016.1148771

Siers, K.P. (2017). Improvement of acceptance of mobile commerce (Bachelor's essay). University of Twente. Retrieved from http://purl.utwente.nl/essays/72687

Silver, L., \& Johnson, C. (2018, October 9). Majorities in sub-Saharan Africa own mobile phones, but smartphone adoption is modest. Pew Research Centre. Retrieved from https://www.pewresearch.org/global/2018/10/09/ majorities-in-sub-saharan-africa-own-mobile-phones-but-smartphone-adoption-is-modest/ 
Slade, E., Williams, M., Dwivedi, Y., \& Piercy, N. (2015). Exploring consumer adoption of proximity mobile payments. Journal of Strategic Marketing, 23(3), 209-223. https://doi.org/10.1080/0965254x.2014.914075

Solem, R.C. (2015). Limitation of a cross-sectional study. American Journal of Orthodontics and Dentofacial Orthopedics, 148(2), 205-205. https://doi.org/10.1016/j.ajodo.2015.05.006

Statistics South Africa. (2020). Governance, public safety, and justice survey GPSJS 2019/20. Retrieved from http:// www.statssa.gov.za/publications/P0340/P03402020.pdf

Straub, E.T. (2009). Understanding technology adoption: Theory and future directions for informal learning. Review of Educational Research, 79(2), 625-649. https://doi.org/10.3102/0034654308325896

Tabachnick, B.G., \& Fiddell, L.S. (2013). Using multivariate statistics (6th ed.). Pearson.

Thakur, R., \& Srivastava, M. (2014). Adoption readiness, personal innovativeness, perceived risk and usage intention across customer groups for mobile payment services in India. Internet Research, 24(3), 369-392. https://doi.org/10.1108/intr-12-2012-0244

Tian-Que, L. (2012). Perceived risk in marketing strategy. In M. Zhu (Ed.), Business, economics, financial sciences, and management. Springer.

Toplin, J. (2021). What's pushing growth in proximity mobile payment usage?. Retrieved on June 4, 2021 from https:/www.businessinsider.com/proximity-mobile-payment-usage-continues-to-grow-2021-6? IR=T

World Population Review. (2020). Crime rate by country 2020. Retrieved on March 14, 2020 from https:// worldpopulationreview.com/countries/crime-rate-by-country/

Wu, K., Vassileva, J., \& Zhao, Y. (2017). Understanding users' intention to switch personal cloud storage services: Evidence from the Chinese market. Computers in Human Behavior, 68, 300-314. https://doi.org/10.1016/j.chb.2016.11.039

Yang, K., \& Lee, H. (2010). Gender differences in using mobile data services: Utilitarian and hedonic value approaches. Journal of Research in Interactive Marketing, 4(2), 142-156. https://doi.org/10.1108/17505931011051678

Yang, Y., Liu, Y., Li, H., \& Yu, B. (2015). Understanding perceived risks in mobile payment acceptance. Industrial Management \& Data Systems, 115(2), 253-269. https://doi.org/10.1108/imds-08-2014-0243

Zhang, Y., Sun, J., Yang, Z., \& Wang, Y. (2018). What makes people actually embrace or shun mobile payment: A cross-culture study. Hindawi Mobile Information Systems, 7497545. https://doi.org/10.1155/2018/7497545

Zhou, T. (2013). An empirical examination of continuance intention of mobile payment services. Decision Support Systems, 54(2), 1085-1091.

https://doi.org/10.1016/j.dss.2012.10.034 